\title{
A Reading of Alexander Motyl's Fall River Through the Lenses of Bordermemories
}

Author(s): Tetiana Ostapchuk

Source: Kyiv-Mohyla Humanities Journal 5 (2018): 83-95

Published by: National University of Kyiv-Mohyla Academy

http://kmhj.ukma.edu.ua/ 


\title{
A Reading of Alexander Motyl's Fall River Through the Lenses of Bordermemories
}

\author{
Tetiana Ostapchuk \\ Petro Mohyla Black Sea National University, \\ Institute of Foreign Languages and Literatures
}

\begin{abstract}
This paper examines the concepts of borderlands, borderscapes, and bordermemories as cultural discursive practices that have been extensively presented and analyzed in an increasing number of theoretical works in Border Studies. Contemporary American Ukrainian writers have made attempts to introduce their hybrid experience and include it into American culture. One of them is Alexander J. Motyl, whose novel Fall River (2014) is analyzed as an example of border writing. The novel is based on the author's narrative memory, rooted in his mother's stories about Ukraine and their family members' crossings of borders in the interwar period and belonging to two cultures, Ukrainian and American, that shaped their identities.
\end{abstract}

Key Words: borderscape, borderland, border zones, memories, American Ukrainian national minority.

\section{(2)}

Borders have been at the center of social sciences and humanitarian disciplines since the end of the previous century. The fall of the Berlin Wall in 1989, the collapse of the Soviet Union in 1991, the change of Europe's status in world politics, the increased concern with terrorism, the formatting of a globalized community, and the migration crisis have made Border Studies, with its critical examination of borders and identities, one of the fields that is extremely important in the period of new-era re-/de-bordering. Borders are theorized as geopolitical entities, ${ }^{1}$ everyday practice, ${ }^{2}$ discursive practices, ${ }^{3}$

$1 \quad$ For example, The Ashgate Research Companion to Border Studies, edited by Doris Wastl-Walter (Burlington, Vt.: Ashgate, 2011) includes parts entitled "Geopolitics: State, Nation and Power Relations," "Border Enforcement in the 21st Century," "Borders and Territorial Identities: The Mechanisms of Exclusion and Inclusion" where the authors analyze the connection between borders, geography and politics. A Companion To Border Studies, edited by Thomas M. Wilson and Hastings Donnan (Chichester, West Sussex: Wiley Blackwell, 2012) concentrates on similar aspects of Border Studies.

2 Concepts of waiting for work, practices of bordering, women and migration to name just a few are under consideration in Parts 5 and 6 in The Ashgate Research Companion to Border Studies.

3 Among many, there is an article by Maria de Fatima Amante, "Local Discursive Strategies for the Cultural Construction of the Border: The Case of the Portuguese-Spanish Border," Journal 
border aesthetics, ${ }^{4}$ borderscapes, ${ }^{5}$ and bordermemories. The last concept is undergoing its current development in a number of projects. One of them is headed by Dr. Karina Horsti, Academy of Finland Fellow. The website Bordermemories proclaims that, "this multidisciplinary project examines the complexities of borders from the perspective of memory politics." ${ }^{6}$ The interrelations between borders as cultural concepts and memories are used by Tatiana Zhurzhenko to analyze two borderlands cities, Trieste and Lviv. In her article "Borders and Memory", she writes: "Borders and borderlands are important sites where the link between collective memory and territory, community and place, 'blood' and 'soil' is established."7

This article aims to investigate the representation of the link between memory and territory in Alexander Motyl's 2014 novel Fall River. ${ }^{8}$ The author was born in New York in 1953 and is a well-known intellectual - he is a writer, a painter, and a professor of Political Science. He is also a third-generation ${ }^{9}$ American Ukrainian whose early education and cultural memory are closely connected with things Ukrainian.

of Borderlands Studies 25.1 (2010): 99-114, in which she analyzes discursive strategies planned by governments and unplanned on an individual level. She makes a valuable for my research statement, that "political borders are mainly mental, symbolic and cultural constructions" and "when confronted with their identity definitions, they [borderlanders] chose to construct their identity through narration" (Amante, "Local Discursive Strategies," 99, 104).

4 See as an example Johan Schimanski and Stephen F. Wolfe, eds. Border Aesthetics (New York: Berghahn, 2017).

$5 \quad$ The concept of borderlands was first theorized by Chicana critic and writer Gloria Anzaldúa. Her most famous quote from Borderlands = La frontera (San Francisco, CA: Aunt Lute Books, 1987 ) is: "Borders are set up to define the places that are safe and unsafe, to distinguish us from them. A border is a dividing line. A narrow strip, along a steep edge. A borderland is a vague and undetermined place created by the emotional residue of an unnatural boundary. It is in a constant state of transition" (Anzaldúa, Borderlands = La frontera, 3). Later, the concept was supported and developed by numerous researchers of Anzaldua's works, and applied to researches in applied and humanities disciplines. Among notable works of the later decade is Prem Kumar Rajaram and Carl Grundy-Warr Borderscapes: Hidden Geographies and Politics at Territory's Edge (Minneapolis: University of Minnesota Press, 2007).

6 Bordermemories, accessed November 18, 2017, https://bordermemories.wordpress.com.

7 Tatiana Zhurzhenko, "Borders and Memory," in The Ashgate Research Companion to Border Studies, ed. Doris Wastl-Walter (Burlington, Vt.: Ashgate, 2011), 74.

$8 \quad$ Alexander Motyl, Fall River (Marlboro, NJ: Alternative Book Press, 2014).

9 From here onwards, I will adhere to the following immigration terminology: "According to the United States Census Bureau, the first generation is the first family member to gain citizenship in the country or permanent residency. ... According to immigration activists, second-generation means an individual who was naturally born in the relocated country to one or more parents who were born elsewhere and are not U. S. citizens living abroad" (Dan Moffett, "Is an Immigrant Considered First or Second Generation?" Thought Co., accessed August 22, 2018, https://www.thoughtco.com/first-generation-immigrant-defined-1951570). Normally, the term third-generation is not widely used. The case of Alexander Motyl is 
The Ukrainian national minority in the US is considered to be a relatively young one. In the 2oth century it became politically active in the inter-war period and especially after World War II when Ukrainian intellectuals flowed into the country. Nevertheless, Ukrainian immigrants have not endeavored to narrate their ancestry to an English-speaking audience. Ukrainians, mainly of the second and third waves of emigration have long lived in their established immigrant communities, more or less isolated Ukrainian neighborhoods, maintaining a dream of returning to their native land.10 Thus, these spaces are to be treated as borderlands as they have often been territories where Ukrainian cultural, educational, and religious institutions were created to preserve roots and the Ukrainian language for future generations. At the same time ethnic enclaves have become the places of numerous encounters with American culture and society. The situation was aggravated by the fact that the state of Ukraine under the communist regime was nearly invisible for the Western world. While Ukraine was framed as a borderless province of Russia and as a part of the USSR, Ukrainians in the United States also faced multiple problems connected with their cultural identification. For example, this is how one prominent contemporary writer, Askold Melnyczuk, describes his experience of being a member of a Ukrainian community:

For my generation, growing up Ukrainian was something that seemed to happen almost in secret. ... Those of us experiencing American schools for the first time were shocked to find out that far from being the center of the Universe, Ukraine had no place at all in the awareness of most of our peers, or for that matter, our teachers. ${ }^{11}$

Further, he stresses how the situation changed after Ukraine gained its independence:

How many Ukrainian-Americans of my generation felt like Martians who had been raised by our own kind in the security of

somewhat different because his grandparents were representatives of first-wave Ukrainian immigrants to the USA. After his grandmother's death his grandfather returned to Ukraine with his children, second-generation Americans born in the US with American citizenship, one of them being Motyl's mother. The children fled back to the United States in 1938 and 1947. Alexander was born in New York in 1953. So, the term "third-generation" is used in the article to keep the situation chronologically clear for readers.

10 This statement, however, might be disputed as a problematic stereotype, living in ethnic ghettos and dreaming about a home country are repetitive motifs which are typical for émigré culture and writings.

11 Askold Melnyczuk, "Under Western Eyes: Images of Ukraine in Contemporary American Fiction," in American Literature at the Edge of 2oth and 21st Centuries, ed. Tamara Denysova (Proceedings of the Second International Conference on American Literature, Kyiv, September 24-26, 2002) (Kyiv: Institute of International Relations Publishers, 2004), 429. 
our homes by parents who forgot to tell us before we went out into the world that we should wear scarves to cover the bolts on our necks. ... All that changed when you reclaimed your self-possession in 1991 — and I felt then, and continue to feel today, such relief that it leaves me with great sympathy for people anywhere in the world facing similar forms of subtle erasure or even complete cultural and spiritual annihilation. ${ }^{12}$

These witnesses explain well why the Ukrainian historical migrants' offspring, with their specific values could enter into the mainstream of modern American culture only at the end of the 2oth century. In the sphere of literary production, representatives of the second and following generations of immigrants have made significant contributions into the process of the visualization of the Ukrainian part of the diverse multi-/ transcultural America of the present day. Contemporary American Ukrainian writers tend to comprehend their hybrid experience and their (grand)parents' experience as migrants and/or refugees, while using the English language, literary forms, and genres understandable for a global audience, thus, inscribing their narratives into a wider paradigm of migrant border writings. For example, the first novels of such well-know American Ukrainian authors as Askold Melnyczuk (What Is Told, 1994; Ambassador of the Dead, 2001; House of Widows, 2008), Irene Zabytko (The Sky Unwashed, 2000; When Luba Leaves Home, 2003), Daniel Hryhorczuk (Caught in the Current, 2013), Orest Stelmach (The Boy From Reactor 4, 2013; The Boy Who Stole from the Dead, 2014; The Boy Who Glowed in the Dark, 2014; The Altar Girl, 2015), and Michael Naydan (Seven Signs of the Lion, 2016) are all connected with their experience of living in-between two cultures, often inspired by their family narratives. The settings of their novels are located at the crossroads of America and Ukraine. The authors also vary genres of their texts: thrillers, detective stories, autobiographical stories, travel writing, etc. As Alexander C. Diener states:

Individual and groups are not born with blood linked to soil. This bond is constructed and must be analyzed in relation to specific narratives of community, society, and state - each of which are performed with profound impacts around political borders. ${ }^{13}$

In all his novels, Alexander Motyl constructs bonds with his own American and Ukrainian heritage, that of his family, and the national minority he belongs to. ${ }^{14}$

12 Melnyczuk, "Under Western Eyes," 43 o.

13 Alexander C. Diener, "The Borderland Existence of the Mongolian Kazakhs: Boundaries and the Construction of Territorial Belonging," in The Ashgate Research Companion to Border Studies, ed. Doris Wastl-Walter (Burlington, Vt.: Ashgate, 2011), 39o-91.

14 Alexander Motyl is a highly acclaimed specialist on Ukraine, Russia, and the USSR, and on nationalism, revolutions, empires, and theory. He has published a dozen non-fiction books. 
Fall River is based on the life stories and personal memories of the author's mother, uncle, and aunt. In the Preface, Motyl remarks:

And because almost all my parents' immediate family and more distant relatives lived under communist regimes in Ukraine, Poland, and Czechoslovakia, Fall River became, perhaps inevitably, the only immediate connection I had with my family history and my "roots." 15

Here, the direct connection between the exact territory, the city of Fall River in Massachusetts, and collective memory of the family as a unified group is openly proclaimed. The word "roots" can be decoded as something that connects the author with the homeland of his parents, their past, their cultural heritage, their beliefs, and the stories of their borders crossings. The inverted comma signals that the author questions these concepts as his personal roots, in other words his roots as an American-born citizen. In the following sentence he continues: "The city progressively assumed a wellnigh mystical stature as an 'imagined homeland."'16 The allusion to Benedict Anderson's concepts is straightforward, as well as his representation of "a nation as an imagined political community." ${ }^{17}$ Motyl depicts Fall River not only as an American city where his ancestors-immigrants lived, but as a space where a mental image of their Ukrainianess was maintained by their narratives. The writer proceeds to explain the nature of the novel: "This novel is, thus, ninety-five parts fiction and five parts fact... It goes without saying that, like any work of fiction, Fall River has no relationship whatsoever to truth or Truth or anything in between." 18 Within such an interpretation the reader faces a narrative whose genre can be described as a fictional (auto)biography and travel / border writing. The three main characters - Uncle Mike, Mother Maria, and Aunt Stefa - were born in Fall River in the United States into a Ukrainian immigrant's family, however their father decides to return to Ukraine after his wife's death. The four of them arrive in the Polish-Ukrainian borderland in the interwar period, and subsequently the three grown-up children return to the US one by one.

He has also maintains blogs in which he analyzes Ukrainian policies concerning Ukraine in the world. Motyl's fiction writings (Ardor, 2016; Vovochka, 2015; Fall River, 2014; Sweet Snow, 2013; My Orchidia, 2012; The Jew Who Was Ukrainian, 2011; Who Killed Andrei Warhol, 2007; Flippancy, 2007; and Whiskey Priest, 2005) blend Ukrainian themes, world affairs, and his personal narratives in a very experimental manner. 


\section{Border Zones}

There are different types of borders in the novel: geographical borders between countries and continents to be crossed by migrants; invisible borders within the same country to divide representatives of different regimes, political, and religious groups; temporal borders between the Selves of characters at a given moment and in their own past; borders between reality and dreams, life, and death.

In the first chapter, entitled "Mike," the author uses a second person narrative strategy that allows a dialogue with his uncle's feelings, emotions, memories, and thoughts. Motyl depicts different scenes in Mike's life using his own voice interlaced with many rhetorical questions. Here is an extract describing Mike's travel from Ukraine back to the US:

It is 1938, you are barely nineteen and you are about to board a train for Hamburg. There, while desperately clinging to the slick railing, you will mount a ramp and become one of hundreds of bundled passengers on the President Roosevelt, a mighty American ship that will, after two weeks on the rough waters of the North Atlantic, dump you in a country that is no longer your country and a home that is no longer your home. ... Who wouldn't feel uncertain, who wouldn't be terrified at the prospect of negotiating an enormous body of water on one's own? And especially someone like you, who may never have been in Lviv, or Lemberg or Lwów on his own?19

In this passage, the author restores a typical route of second-wave Ukrainian immigrants to America through Europe. The Atlantic Ocean is shown as a natural border between two continents that can be crossed only on a mighty American ship. Moreover, in all of the chapters the characters recollect their crossings of the ocean as a very harrowing experience demanding all their strength and patience. The ocean's turbulence is a symbol of the refugees' fate. The concept of home is also questioned in the above extract: What is home? Where is home? Is it the place of birth? Or is it a place that you feel an inner connection with? Motyl does not give direct answers to the underlying perpetual mode of homelessness for any migrant. Mentioning Lviv/ Lemberg/Lwów clearly marks the part of Europe that hosted Mike and his siblings as a border zone. Three different ways of spelling the name of the same city direct a reader to its Ukrainian, Austro-Hungarian, and Polish historical periods. In the subsequent chapters the author shows this territory as a space of conflicts for Soviets, Germans, and Ukrainian nationalists.

Whilst Mike is living in the US he finds many similarities between society's attitude to African American minorities and Ukrainians back in Europe: 
And then you see the difference between them and us. The nigger gets to his feet and, amazingly, excuses himself and, smiling so weakly that even his white teeth don't show, runs off. This, you think, would never have happened at home. The Ukrainian would have waved his fist and gone for his friends. There would have been a brawl and some Polish heads would've been cracked. And, you think, we don't have it half as bad as niggers. Why don't they fight? Why do they always smile? And then it strikes you: they're like terrified dogs that have been systematically beaten. They slink along the walls with lowered heads and tails. The Poles, Russians, and Jews want us to be that way, too, you think, but we have a backbone and a will. We will not submit. ${ }^{20}$

Clearly, the author intensifies the narration with his own doubts and thoughts, attempting to crystallize Mike's personal and collective identity through the strategy of othering and maintaining symbolic borders with other ethnic and national groups. Western Ukraine is represented as a liminal space, simultaneously dangerous and culturally diverse, although it is clearly perceived as home after the main character has crossed its borders forever and has found himself in a state of constant fluctuation between his past and present. Naturally, New York is also described as a border zone crowded with buildings, noises, people, transport, etc. The writer uses the stylistic device of enumeration to restore the atmosphere of rush and abundance of things there. The very first impression Mike has is from an accident at a crossing of two streets that may be interpreted symbolically as a prediction of bad luck for him after he has chosen his path at the crossroads of countries, cultures, and memories. Because Mike cannot adapt to life in New York, he enters the Civilian Conservation Corps and moves to Oregon. On the way Mike names New York as the home that he has to leave to become a man. Again and again, the very concept of home is unstable; it is permanently challenged and questioned. For example, in the following chapter, entitled "Manya," in which Mike's elder sister, the author's mother, is a narrator who confesses her life story, she voices the following idea: "Where, exactly, among these skyscrapers, mountains, and trees would I fit in and find a home? I had no idea, except that Mike would be my home." ${ }^{21}$ The pages describing Mike's way to the West are full of descriptions of train movement and the character's doubts about his future. Motyl uses the techniques of flashbacks and flash forwards to represent his character in a constant flux between his past and future, between Ukraine and the US, and between the openness of the American landscape that is a symbol of opportunities and the vast possibilities of this country and the confines of Mike's forthcoming imprisonment in a mental ward.

Thus, the author shows his character within spatial and temporal borders. The last concept is distinctly visualized with the help of two images: a song and a camera. 
Mike often sings the song "Smoke Gets in Your Eyes," which becomes a very important feature of his individuality. It is presented as an emblematic link to his American Self, as a mechanism that helps him be included into American society, to find love and respect at least for a short period of his life. Back in Ukraine, the same song is sung by another character in the novel-Bohdan, Stefa's husband, a member of a nationalist underground Organization, a fighter for the rights of Ukrainians who is under surveillance by the Polish, Soviet, and German regimes. Once in prison, he learns the words of the song from another inmate, and after he is released Bohdan proclaims

indifference to the world and its tribulations that shaded into a near-religious devotion to the only things that mattered to Bohdan, the ideas or ideals that gave his life meaning and, thus, endowed him with spiritual gratification. "Smo'getsinyorize" and Ukraine were all that really mattered.22

The song becomes a prayer, a spiritual formula, a mechanism of survival, and Bohdan's last words together with "Slava Ukraini!" (Glory to Ukraine) before his martyr death at the hands of NKVD agents. All in all, two characters are connected via a song that has no spatial or temporal limits. However, Mike and Bohdan are juxtaposed: Bohdan dies for his native land and his beliefs physically, while Mike dies mentally in a foreign country. As Motyl writes metaphorically, "There is also the smoke that gets in your eyes," ${ }^{23}$ which means that Mike has been gradually losing his connection with his environment. He has started to see things and people from his past; the borders between reality and dreams, the present moment and memories have disappeared; and his Self has been dissolved while losing connection with his symbolic borderland: "Time appears to stand still or, perhaps more accurately, it appears to have ceased altogether, to have become obliterated and disappeared. It doesn't much matter anymore just where time is or is not experienced..." ${ }^{24}$ The phrase in italics demonstrates the tight connection between time and a particular landscape, and the overwhelming destruction of a personal identity under the uncontrolled intrusion of memories.

Another image connected with temporal borders is Mike's obsession with photography. The existence or non-existence of his photos gives way to the author's speculations about his uncle's past in a way that protrudes borders of the past into the present. Thus, photos are specific memory practices allowing the creation of narratives to support the connection between "blood" and "soil." For Mike, his camera has become "blessed, wonderful, magnificent, God-fearing" 25 as it gives him a chance to imprint reality in his mind and literally see the past through its lenses.

\footnotetext{
22 Motyl, Fall River, 115.

23 Motyl, Fall River, 48.

24 Motyl, Fall River, 51.

25 Motyl, Fall River, 44.
} 
In the finale of the chapter, Mike dies. After he is institutionalized, "there is no memory and no experience." ${ }^{26}$ Motyl writes about his uncle's death in a very vivid manner, gathering symbols from the entire chapter in just three sentences: "For a brief time, you enjoyed expansiveness and possibility. Life was a train sailing along the steppes. And then the walls came in on you and the lights were turned off." ${ }^{27}$ Such are the borders between life and death.

\section{Memories as Borders}

The very essence of Motyl's novel is to share memories of his family's past and give them a passage into the present. Narrating the memories of his mother and relatives can help the author to set boundaries between the past and his personal Self. This aspect is extensively covered in border aesthetics: "[These] border-crossing narratives depict individuals and communities negotiating with placelessness, language, ethnicity and sexualities in hybridized discourses of resistance and ambivalence." ${ }^{28}$ Motyl has also created a multi-dimensional narrative in the sense that he has written three chapters from three different points of view: first, second, and third person narratives overlap and present memories about the same events in a dialogical way, intensifying the impression of negotiation between the participants in that aesthetic dialogue. Writing about real bordermemories, but also implementing borders into the very strategy of writing, Motyl, in tune with the quote that "bordering is ordering, othering and negotiating difference" 29 orders, others, and negotiates his personal, collective, and national identity.

Though, as it is known, any border is a meeting place, a location of contact. Insofar as the city of Fall River has been a borderland where the first Ukrainian immigrants met with the Portuguese and Irish émigré communities and interacted with American culture; the Ukrainian ethnic community of Fall River has become a borderspace for the author as it is there he experienced contacts with the Ukrainian language and traditions; the novel Fall River is a discursive contact with the personal and universal bordermemories of migrants.

The author uses different strategies in all three chapters to voice memories. In the opening paragraphs the author underlines the idea of the "reconstruction" of the past as no memories or experience exist. The artifacts that do exist cannot render truth about the past. In the first chapter he speculates much about these notions. For example, Motyl finds similarities between his memories and Mike's: "A four-year old has blurry memories or empty memories, almost as blurry and empty as mine, which, as you know, are non-existent." ${ }^{30}$ In the second chapter, the first person narrator, the

\footnotetext{
26 Motyl, Fall River, 54 .

27 Motyl, Fall River, 54.

28 Mireille Rosello and Stephen F. Wolfe, "Introduction," in Border Aesthetics: Concepts and Intersections, ed. Johan Schimanski and Stephen F. Wolfe (New York: Berghahn, 2017), 12. Rosello and Wolfe, "Introduction," 12. 
author's mother, bears witness of her experience of her mother's death and departure to Ukraine, several border-crossings, the trauma of World War II, DP camps, and the burden of memories that a person has to get rid of through narration:

The war had destroyed everything. It had destroyed our town and its inhabitants. It has my family and friends. And it had also destroyed my memories. What was there to remember? There had been good times and good memories, but the bad times and bad memories so outweighed them that it became far easier to forget and refuse to remember that to remember. But a person without memories is not a human being. ${ }^{31}$

The third chapter, written in the third person about the author's aunt Stefa, establishes the connection between memories and storytelling: "Stefa couldn't share this memory of the house, because it, too, wasn't a real memory, but a story." ${ }^{2}$ Finally, Motyl ends his novel: "The absence of memories and experiences is notable, of course, but the beginnings, middles, and ends are in place and form something in the nature of a coherent narrative." ${ }^{33}$

An additional approach to interpret such discursive strategies of the writer exists. Modern theoretical discourse on trauma, memory, witnessing, and the crisis of witnessing is booming in different spheres of knowledge. It seems that Alexander Motyl is studying the same concepts and ideas but in the form of fiction. As stated in various research, a dialogue with a traumatized witness is a powerful tool in working through trauma and coping with post-traumatic syndrome. From this perspective, Motyl's numerous dialogues - between the author and the narrator, between the narrator and three main characters, between the main characters through the strategy of re-presenting particular events from three different angles - may have the aim of giving his ancestors the opportunity to become true witnesses and to overcome their traumas. On the other hand, "Trauma research confirms that unbearable events tend to be pushed to the margins of consciousness. Yet that which cannot be acknowledged in the first generation of survivors might impose itself on the second in undefined absences or enacted repetitions." ${ }^{34}$ In Motyl's case, as well as in many similar cases,,35

31 Motyl, Fall River, 88.

32 Motyl, Fall River, 103.

33 Motyl, Fall River, 149 .

34 Claudia Welz, "Trauma, Memory, Testimony: Phenomenological, Psychological, and Ethical Perspectives," in Jewish Studies in the Nordic Countries Today 27 (2016): 105.

Cf:: The motif of the crisis of the witness for the first generation of Ukrainian immigrants in the USA is present in nearly every text written by representatives of following generations. I want to mention only two texts in which this idea has been openly discussed: several stories in When Luba Leaves Home by Irene Zabytko uncover the impossibility of a dialogue between the main character, Luba, and her parents concerning their past, especially their stay in DP camps; another novel, The Silence of Trees by Valya Dudycz Lupescu, is entirely grounded on the idea 
the traumatic experience of Ukrainian refugees has undergone transgenerational transmission and, quoting Volkan,

As the chosen trauma passes from generation to generation it changes function. The historical truth about the event is no longer important for the large group, but what is important is that through sharing the chosen trauma, members of the group are linked together. In other words, the chosen trauma is woven into the canvas of the ethnic or large group tent, and becomes an inseparable part of the group's identity. ${ }^{36}$

In Fall River Motyl literally embarks to witness in place of his dead ancestors, though truth, as he states at the very beginning, is no longer important because narrating memories about trauma transforms his personal voice into the collective voice of an entire group of American Ukrainians. Thus, the author re-borders his identity while reconstructing the past through the narration of the trauma, displacements, and memories of his ancestors.

\section{Conclusion}

Fall River is a good example of border writing not only because it tells a story of migrants, bordercrossings, borderlands, and temporal borders between selves in the present and in the past, but also because the story is told from the perspective of an American Ukrainian intellectual who is himself at the crossroads of continents, countries, nations, borders, memories, etc. The novel expands the borders of American literature and culture while incorporating the experience of Ukrainian migrants and the Ukrainian national minority into the concept of "American" identity and culture. Simultaneously, it challenges Ukrainian literature and culture to include such border texts into its canon as well as to re-consider the conception of "Ukrainian" identity and culture. The analysis of texts like this one from the perspective of Border Studies has proven to be a productive critical tool that turns attention "away from creating narratives about coherence of cultures within national borders to an analysis of what Carolyn Porter has called 'cultural force fields,' border zones in which individual and national identities migrate, merge, and hybridize." ${ }^{37}$

of silencing the past and its destructive influence on the present of Ukrainian refugees. Thus, these narratives prove that survivors and real witnesses have transmitted their memories to their children and grandchildren, who, in their turn, have created memory narratives to re-establish a link with the past and to draw a borderline between that past and their own present.

Vamik D. Volkan, "Transgenerational Transmissions and Chosen Traumas," Scribd. com, accessed November 18, 2017, https://ru.scribd.com/document/119720453/TransgenerationalTransmissions-and-Chosen-Trauma. 


\section{Bibliography}

Amante, Maria, Fatima de. "Local Discursive Strategies for the Cultural Construction of the Border: The Case of the Portuguese-Spanish Border." Journal of Borderlands Studies 25.1 (2010): 99-114.

Anderson, Benedict R. Imagined Communities: Reflections on the Origin and Spread of Nationalism. London: Verso, 1991.

Anzaldua, Gloria. Borderlands = La frontera . San Francisco, CA: Aunt Lute Books, 1987 .

Diener, Alexander C. "The Borderland Existence of the Mongolian Kazakhs: Boundaries and the Construction of Territorial Belonging." In The Ashgate Research Companion to Border Studies, edited by Doris Wastl-Walter, 373-93. Burlington, Vt.: Ashgate, 2011.

Dudycz Lupescu, Valya. The Silence of Trees. Chicago, IL: Wolfsword Press, 2010.

Hryhorczuk, Daniel. Caught in the Current. Minneapolis, MN: Langdon Street Press, 2013.

Jay, Paul. Contingency Blues: The Search for Foundations in American Criticism. Madison: University of Wisconsin Press, 1997.

Melnyczuk, Askold. The Ambassador of the Dead. Washington, D. C.: Counterpoint Press, 2001.

Melnyczuk, Askold. The House of Widows. Saint Paul, Minn.: Graywolf Press, 2008.

Melnyczuk, Askold. "Under Western Eyes: Images of Ukraine in Contemporary American Fiction." In American Literature at the Edge of 2oth and 21st Centuries, edited by Tamara Denysova (Proceedings of the Second International Conference on American Literature, Kyiv, September 24-26, 2002), 426-44. Kyiv: Institute of International Relations Publishers, 2004.

Melnyczuk, Askold. What is Told. Boston: Faber and Faber, 1994.

Moffett, Dan. "Is an Immigrant Considered First or Second Generation?" Thought Co. Accessed August 22, 2018. https://www.thoughtco.com/first-generationimmigrant-defined-1951570.

Motyl, Alexander J. Ardor: Or How Would-be Nobel Prize Winner C. Milosz Enjoyed the High Life with Low Life in Italy, Hobnobbed with a Viktor Yanukovych Look-Alike, and Met His Muse on the Rooftop of the Duomo. Augusta, Georgia: Anaphora Literary Press, 2016.

Motyl, Alexander J. Fall River. Marlboro, NJ: Alternative Book Press, 2014. Motyl, Alexander J. Flippancy. New York: Cantara Books, 2007.

Motyl, Alexander J. My Orchidia. Baltimore, MD: BrickHouse Books, 2012.

Motyl, Alexander J. Sweet Snow: A Novel of the Ukrainian Famine of 1933. Somerville, Massachusetts: Cervená Barva Press, 2013.

Motyl, Alexander J. The Jew Who was Ukrainian: Or How One Man's Rip-Roaring Romp Through an Existential Wasteland Ended in a Bungled Attempt to Bump off the Exceptionally Great Leader of Mother Russia. Somerville, Massachusetts: Cervená Barva, 2011. 
Motyl, Alexander J. Vovochka: The True Confessions of Vladimir Putin's Best Friend and Confidant. Augusta, Georgia: Anaphora Literary Press, 2015.

Motyl, Alexander J. Whiskey Priest. New York: iUniverse, 2005.

Motyl, Alexander J., Ivanov, Aleksandr. Who Killed Andrei Warhol: The American Diary of a Soviet Journalist by Oleksandr Ivanov: A Novel. Santa Ana, CA: Seven Locks Press, 2007.

Naydan, Michael M. Seven Signs of the Lion. London: Glagoslav Publications Ltd., 2016. Porter, Carolyn. "What We Know That We Don't Know: Remapping American Literary Studies." American Literary History 6.3 (1994): 467-526.

Rajaram, Prem Kumar, and Carl Grundy-Warr. Borderscapes: Hidden Geographies and Politics at Territory's Edge. Minneapolis: University of Minnesota Press, 2007.

Schimanski, Johan and Stephen F. Wolfe, eds. Border Aesthetics: Concepts and Intersections. New York: Berghahn, 2017.

Stelmach, Orest. The Altar Girl. Seattle: Thomas \& Mercer, 2015.

Stelmach, Orest. The Boy from Reactor 4. Seattle: Thomas \& Mercer, 2013.

Stelmach, Orest. The Boy Who Glowed in the Dark. Seattle: Thomas \& Mercer, 2014.

Stelmach, Orest. The Boy Who Stole from the Dead. Seattle: Thomas \& Mercer, 2014.

Volkan, Vamik D. "Transgenerational Transmissions and Chosen Traumas." Scribd. com. Accessed 18 November 2017. https://ru. scribd. com/document/119720453/ Transgenerational-Transmissions-and-Chosen-Trauma.

Wastl-Walter, Doris, ed. The Ashgate Research Companion to Border Studies. Burlington, Vt.: Ashgate, 2011.

Welz, Claudia. "Trauma, Memory, Testimony: Phenomenological, Psychological, and Ethical Perspectives." Jewish Studies in the Nordic Countries Today 27 (2016):104-33.

Wilson, Thomas M. and Donnan Hastings, ed. A Companion to Border Studies. Chichester, West Sussex: Wiley Blackwell, 2012.

Zabytko, Irene. The Sky Unwashed. Chapel Hill, N. C.: Algonquin Books of Chapel Hill, 2000.

Zabytko, Irene. When Luba Leaves Home. Chapel Hill, N. C.: Algonquin Books of Chapel Hill, 2003.

Tetiana Ostapchuk is an Associate Professor at the Institute of Foreign Languages and Literatures at the Petro Mohyla Black Sea National University in Mykolaiv, Ukraine. She was a Fulbright Scholar at Pennsylvania State University in 2007 and 2008. Trained as a comparativist, she has published and lectured extensively on topics of Ukrainian American literature, memory, and identity in contemporary Ukrainian and American narratives, the representation of trauma in audio-visual art, and Chornobyl in American popular culture. 